\title{
Self-Control pada Anak Jalanan Usia Remaja di Kota Serang dan Alternatif Penangannya dalam Bimbingan dan Konseling
}

\author{
Ade Thia Indiyani ${ }^{1}$, Meilla Dwi Nurmala ${ }^{2}$, Alfiandy Warih Handoyo ${ }^{3}$ \\ ${ }^{123}$ Universitas Sultan Ageng Tirtayasa
}

Email: adethiaindiyani92@gmail.com

\begin{abstract}
ABSTRAK
Penelitian dilatarbelakangi oleh maraknya keberadaan anak jalanan di Kota Serang yang disertai oleh stigma negatif dari masyarakat terhadap perilaku anak jalanan di Kota Serang. tujuan penelitian yaitu untuk mengetahui serta memahami gambaran self-control pada anak jalanan usia remaja, mengetahui faktor yang mempengaruhi self-control pada anak jalanan serta untuk menentukanalternatif layanan bimbingan dan konseling apa yang dapat diberikan oleh konselor kepada anak jalanan usia remaja di Kota Serang dalam meningkatkan self-control. Penelitian ini menggunakan pendekatan kualitatif dengan metode penelitian studi kasus. Penentuan informan pada metode ini menggunakan metode purposive sampling. Setting pada penelitian ini dilakukan di Kota Serang. Metode pengumpulan data dalam penelitian diperoleh dengan melalui observasi tak terstruktur, wawancara secara langsung, semi terstruktur dan formal serta dengan menggunakan metode dokumentasi. Uji keabsahan data dilakukan dengan menggunakan metode triangulasi sumber data. Adapun dalam analisis data yaitu dengan menggunakan teknik reduksi data, sajian (display) data dan penarikan kesimpulan. Hasil dari penelitian menunjukan bahwa anak jalanan usia remaja di Kota Serang memiliki kemampuan kontrol diri yang cukup atau dapat dikatakan sudah cukup mampu mengontrol dirinya. Faktor yang melatarbelakangi self-control pada anak jalanan yakni adanya faktor usia dan juga lingkungan keluarga. Disamping itu, terdapat faktor lain yang cukup mempengaruhi kontrol diri pada anak jalanan yaitu adanya pengaruh pendidikan pada anak jalanan. Pendekatan Realitas dengan menggunakan teknik WDEP merupakan alternatif bantuan dari layanan bimbingan dan konseling yang dirasa sesuai dan tepat untuk meningkatkan self-control pada anak jalanan usia remaja di Kota Serang.
\end{abstract}

Kata Kunci : self-control; faktor yang mempengaruhi; konseling; pendekatan Realitas; WDEP.

\section{ABSTRACT}

This research is motivated by the rampant existence of street children in Serang City which is accompanied by a negative stigma from the community towards the behavior of street children in Serang City. The research objectives are to find out and understand the picture of self-control in street children in adolescence, to find out the factors that influence self-control in street children and to determine what alternative counseling and guidance services can be provided by counselors to teenage street children in Serang City. improve self-control. This study uses a qualitative approach with a case study research method. Determination of informants in this method using purposive sampling method. The setting in this study was carried out in Serang City. The data collection method in this research was obtained through unstructured observation, direct interviews, semi-structured and formal and by using the documentation method. The data validity test was carried out using the triangulation method of data sources. As for data analysis, namely by using data reduction techniques, data display and drawing conclusions. The results of the study show that street children in the city of Serang have sufficient self-control skills or can be said to be able to control themselves enough. The factors behind self-control in street children are age and family environment. In addition, there are other factors that are sufficient to influence self-control in street children, namely the influence of education on street children. Reality approach using WDEP technique is an alternative assistance from services guidance 
and counseling that are deemed appropriate and appropriate to improve self-control in street children of adolescence in Serang City.

Keywords: self-control; influencing factors; counseling; Reality approach; WDEP.

\section{PENDAHULUAN}

Kematangan emosi menurut Yusuf (Amiril, 2013: 2) adalah suatu kemampuan yang dimiliki oleh setiap individu untuk bersikap menghargai, merasa mempunyai kontrol dalam diri, nyaman, dan mampu mengungkapkan perasaan emosinya. Individu yang telah memiliki kematangan secara emosional mampu menentukan dengan bijak tentang kapan dan sampai mana dirinya untuk turut serta dalam suatu permasalahan sosial yang juga harus mampu dalam memberikan solusi atau pemecahan masalah yang diperlukan Gorlow; Lugo dalam (Muawanah \& Pratikto, 2012: 492). Pada akhirnya kematangan emosi sangat berperan penting dalam mengembangkan kontrol diri.

Chaplin dalam (Adeonalia, 2002: 36) menjelaskan mengenai kontrol diri atau selfcontrol sebagai suatu kemampuan yang dimiliki oleh inidvidu untuk dapat mengarahkan tingkah lakunya sendiri dan merupakan kemampuan yang berfungsi untuk menekan atas dorongan yang ada. Dengan memiliki self-control individu tersebut akan mampu mempertimbangkan segala konsekuensi yang akan terjadi pada dirinya, sebelum memutuskan sesuatu untuk bertindak serta mampu mengarahkan energi emosi pada bagian ekspresi yang bermanfaat dan dapat diterima secara sosial (Amiril, 2013: 2).

Kontrol diri atau self-control pada remaja terlihat dari bagaimana cara mereka dalam mengendalikan perilaku, mengendalikan kognitif serta dalam mengambil keputusan. Sejalan dengan yang disampaikan oleh B. Slamet (Rahman, 2014: 19) memaparkan bahwa remaja yang memiliki kemampuan dalam self-control akan terlihat pada saat remaja tersebut dapat mengetahui tentang apa yang dapat dan tidak dapat dipengaruhi dengan berdasarkan tindakan pribadi dalam sebuah keadaan. Apabila remaja tersebut mampu memfokuskan diri pada bagian yang perlu di kontrol dan meyakini atas pilihan tindakannya maka remaja tersebut telah mampu untuk berperilaku dengan baik dan sukses. Dengan memilki self-control dapat membantu remaja dalam berpikir dan berperilaku yang lebih terarah, dan juga mampu mengarahkan akan dorongan perasaan dalam dirinya dengan benar dan tidak melanggar norma dan aturan-aturan yang 
berlaku di lingkungan sekitarnya (Astuti, dari perlakuan yang dihargai, hal ini 2019: 5).

Remaja merupakan masa peralihan disebabkan karena sebagian besar dari mereka yang berada pada usia relatif dini sudah harus dari masa kanak-kanak hingga menuju masa dewasa, yang dimulai pada usia 12 sampai 13 tahun hingga pada usia 20 tahun, perubahan yang terjadi meliputi semua aspek perkembangannya yaitu perkembangan fisik, kognitif, kepribadian, dan sosial (Gunarsa, 2006: 196). Perubahan yang terjadi selama masa remaja menyebabkan remaja berisiko mengalami gangguan tingkah laku dan terjadinya kekerasan, baik sebagai korban atau pelaku dari tindak kekerasan. Pengendalian diri akan lebih mudah terbentuk untuk orangorang yang berada di lingkungan yang terarah atau formal, misalnya sekolah ataupun rumah. Tetapi kontrol diri atau self-control ini akan lebih sulit jika berada di lingkungan yang jauh dari pengawasan dan pantauan, seperti di lingkungan sosial yang cenderung banyak melakukan kegiatan di jalanan. Mereka yang kerap kali melakukan aktivitas di jalanan biasa disebut dengan anak jalanan.

Menurut Dapertemen Sosial RI (Mubarok, 2016: 4) mendefinisikan anak jalanan yaitu sebagai anak yang hampir kebanyakan menghabiskan waktunya dijalanan atau tempat-tempat umum di pusat kota untuk mencari nafkah. Anak jalanan memiliki pengertian yaitu anak-anak yang harus merasakan dirinya tersisih, dan marginal merasakan dan berhadapan dengan keadaan kota yang keras, serta sangat tidak rukun (Lestari, 2019:1).

Anak jalanan yang berada di Kota Serang lebih banyak menjadi pengamen dikarenakan mengamen tidak memerlukan banyak alat ataupun modal yang harus dikeluarkan oleh mereka. Dalam hal ini, peneliti tertarik untuk melakukan penelitian terhadap anak jalanan yang menjadi pengamen di Kota Serang. Sebagian anak jalanan cenderung mendapatkan dukungan dari orang tuanya untuk beraktivitas di jalanan (Astri, 2014, p. 149). Maka dari itu penting bagi anak jalanan usia remaja untuk memiliki selfcontrol yang baik di kehidupannya.

self-control memiliki peran dalam menunjukkan siapa diri kita (nilai diri). Seringkali, anak jalanan dianggap sebagai pribadi yang negatif dan merusak. Fenomena anak jalanan yang keberadaannya kerap kali dipandangan sebagai pengganggu ketertiban oleh masyarakat merupakan sebuah resiko atau konsekuensi logis dari adanya stigma sosial dan keterasingan mereka dalam masyarakat. Banyaknya yang tidak berpihak kepada mereka sebenarnya menjadikan perilaku merekalah yang mencerminkan cara 
PEDAGOGIKA

Volume 12 (Nomor 2) 2021

HaL. 217-231

masyarakat memperlakukan mereka (Suryanto, 2010).

Menurut Ali Khomsan (Nurfaujiyanti, 2010: 3) jika anak jalanan tidak memiliki kontrol diri atau self-control maka akan menimbulkan perilaku anti sosial, seperti sering berkelahi, menggertak/mengancam atau bahkan berperilaku agresif lainnya yang dapat merugikan diri sendiri ataupun masyarakat sekitar. Namun sebaliknya, menurut Rahman (2014: 24) apabila anak jalanan mampu mengontrol dirinya dari hal-hal yang negatif maka dirinya akan mendapatkan respon dan penilaian yang positif dari lingkungan sosialnya, dan mampu melakukan sesuatu yang dapat diterima oleh lingkungan sekitar (masyarakat) serta mampu memahami dan mengatur kontrol diri yang dibutuhkan untuk memenuhi kebutuhannya dan sesuai dengan apa yang di inginkan oleh masyarakat, selain itu mampu menilai suatu keadaan secara kritis sebelum memberikan respon dan memutuskan atas tindakan yang akan dipilihnya. Pengarahan dan bimbingan bagi anak jalanan usia remaja sangat diperlukan dalam membetuk self-control yang baik bagi dirinya agar mampu menahan atau mengendalikan tingkah laku negatif agar tidak merugikan diri sendiri dan orang lain, serta mampu memposisikan dirinya secara baik dengan keluarga, teman maupun masyarakat. Sehingga, perlunya pengentasan masalah serta

penanggulangan yang efektif dalam permasalahan self-control pada anak jalanan usia remaja. Perlunya keterlibatan orang ahli serta berkompeten yang dapat dipercaya individu dalam menyampaikan isi pikiran dan perasaannya sehingga individu tidak salah dalam mendapatkan arahan atau saran. Salah satu pihak yang berperan penting dalam mengatasi individu usia remaja adalah bimbingan dan konseling (BK).

Sederhananya, bimbingan dapat dimaknai sebagai upaya preventif sedangkan konseling merupakan upaya kuratif atas suatu permasalahan yang dihadapi konseli. Adanya proses konseling oleh seorang konselor akan cukup mampu dalam mengatasi permasalahan self-control pada anak jalanan usia remaja dengan layanan dan pendekatan yang sesuai dengan latar belakang, aspek serta faktor yang mempengaruhi self-control pada anak jalanan usia remaja. Dengan adanya kolaborasi ini diharapkan mampu mencegah perilaku negatif yang dilakukan anak jalanan usia remaja dengan meningkatkan self-control pada diri mereka. Kolaborasi juga dapat mereduksi stigma negatif masyarakat terhadap anak jalanan.

\section{METODE PENELITIAN}

Jenis penelitian yang digunakan peneliti adalah studi kasus. studi kasus merupakan studi yang digunakan untuk 
mengidentifikasi permasalahan yang terjadi dalam kehidupan nyata saat ini, dengan berfokus pada jawaban "bagaimana" dan “mengapa". Metode penelitian ini menggunakan pendekatan kualitatif. Metode penelitian kualitatif didefinisikan Sugiyono (2012: 9) sebagai metode penelitian yang didasarkan pada filsafat post-positivisme, dalam hal ini peneliti adalah instrumen kunci, teknik pengumpulan data dikembangkan melalui triangulasi dan analisis data bersifat induktif/kualitatif, dan hasil studi lebih menekankan pada makna daripada melebihlebihkan.

Tujuan dari penelitian kualitatif adalah menjelaskan kebenaran suatu fakta secara mendalam, terperinci dan tuntas. Pendekatan kualitatif dipilih, karena berfokus pada sifat empiric dengan sasaran penelitian berupa permasalahan yang terjadi pada masa kini. Pengumpulan data yang digunakan dalam penelitian ini menggunakan triangulasi data. Triangulasi sumber data mengambil dan mempertimbangkan pengolahan data akan kebenaran informasi melalui berbagai metode dan sumber pengolahan data antara lain dengan menggunakan wawancara, observasi dan dokumentasi. Triangulasi sumber data yang digunakan pada penelitian ini yaitu dengan menggunakan hasil observasi, wawancara dan dokumentasi.

$$
\text { Menurut Sutoyo (2009: }
$$

mengungkapkan bahwa observasi merupakan suatu proses pengamatan yang memusatkan perhatian terhadap suatu objek dan gejalagejala yang perlu diamati. Sedangkan wawancara memiliki pengertian yakni percakapan dilakukan dengan adanya maksud tertentu. Selain menggunakan observasi dan wawancara, informasi juga diperoleh melalui dokumentasi. Menurut Rahardjo (2011: 3) memaparkan bahwa dokumentasi ini dapat menghasilkan data sesuai dengan fakta yang tersimpan dalam bentuk surat, asrip foto, jurnal kegiatan, catatan harian, dan sebagainya.

Data yang diperoleh merupakan data yang valid dan harus teruji kebenarannya. Untuk menentukan valid atau tidaknya suatu data penelitian maka diperlukannya pengujian yang disebut dengan uji validitas data dengan syarat data tersebut harus memenuhi kriteria tertentu sehingga dapat dikatakan data yang valid. Untuk menguji dan pemeriksaan validitas data pada penelitian ini dilakukan dengan menggunakan teknik triangulasi sumber data.

Informan yang merupakan subyek dalam penelitian ini adalah tiga orang anak jalanan usia remaja di Kota Serang. Adapun pemilihan subyek dilakukan dengan purposive sampling, yaitu teknik penentuan sampel dengan pertimbangan tertentu (Sugiyono, 
2011: 85). Adapun kriterianya yaitu anak jalanan usia remaja dengan usia antara 12-18 tahun yang melakukan kegiatan mengamen di jalananan atau lampu merah dan berdomisili di Kota Serang, serta bersedia untuk menjadi subyek dalam penelitian. Tempat atau lokasi yang akan dijadikan sebagai tempat penelitian ini adalah beberapa lokasi di sekitar lampu merah wilayah Kota Serang.

\section{HASIL DAN PEMBAHASAN}

\section{Hasil Penelitian}

\section{Self-Control Pada Anak Jalanan Usia}

\section{Remaja di Kota Serang}

Seringkali, anak jalanan usia remaja dianggap sebagai pribadi yang negatif dan merusak. Pada saat mengamen di jalanan, anak jalanan akan lebih rentan mengalami kekerasan ataupun perilaku agresif lainnya serta dapat menimbulkan perilaku anti sosial, seperti sering berkelahi, menggertak atau mengancam yang dapat merugikan diri sendiri ataupun masyarakat sekitar. Sehingga penting bagi anak jalanan usia remaja untuk memiliki self-control sebagai jawaban untuk menolong dan membantu mereka supaya dapat bersikap asertif terhadap dirinya sendiri dan mampu mengungkapkannya kepada orang lain. hal tersebut menjadikan peneliti tertarik untuk meneliti hal tersebut lebih dalam, karena peneliti merasa bahwa penting bagi anak jalanan terutama pada pengamen usia remaja yang ada di Kota Serang untuk memiliki self- control pada diri mereka sehingga tidak mudah untuk melakukan ataupun terpengaruh oleh orang lain dalam suatu hal yang negatif dan dapat merugikan diri sendiri ataupun orang lain.

\section{Kontrol Perilaku pada Anak Jalanan Usia Remaja di Kota Serang}

Kemampuan mengontrol perilaku ini merunjuk berdasarkan kemampuan dalam mengatur pelaksanaan dari suatu perilaku yang mengarah pada suatu hal yang dapat mengganggu kenyamanan orang lain di sekitarnya, sehingga individu tersebut dapat terhindar dari perilaku dan akibat negatif yang bersumber dari situasi yang dihadapinya. Seiring dengan tumbuh dan berkembangnya masa remaja juga erat kaitannya dengan kemampuan mengontrol perilaku dan kematangan emosi yang terjadi pada masa remaja.

Berdasarkan data yang di peroleh, dapat diketahui bahwa terdapat dua subjek yang belum cukup mampu dalam mengendalikan perilakunya. Namun, satu diantara ketiga Informan tersebut sudah cukup mampu dalam mengontrol dirinya, yaitu, kemampuan dalam mengontrol perilaku, kontrol kognitif serta kontrol keputusan.

Kontrol Kognitif pada Anak Jalanan Usia Remaja di Kota Serang

Kontrol kognitif yakni kemampuan dalam mengolah informasi yang tidak 
diinginkan dengan cara menginterpretasi, menilai serta menggabungkan suatu kejadian dalam satu kerangka kognitif untuk mengurangi tekanan yang dihadapinya.

Berdasarkan keterangan yang telah diperoleh dari Informan I, Informan II, dan Informan III melalui wawancara yang telah di lakukan oleh peneliti, terkait kontrol kognitif dapat ditarik kesimpulan sebagai berikut :

a. Informan I, II, dan III mampu menerima dan mengolah informasi yang di perolehnya dengan bijak serta mampu mencari tahu kebenaran dari informasi tersebut.

b. Ketiga Informan tersebut belum sepenuhnya mampu dalam menilai dan menyikapi peristwa yang terjadi pada diri mereka.

Kontrol Keputusan pada Anak Jalanan Usia Remaja di Kota Serang

Kontrol keputusan adalah suatu kemampuan yang dimiliki oleh individu untuk menentukan suatu tindakan atau hasil dengan berdasarkan pada apa yang diyakini atau disetujuinya. Berdasarkan keterangan yang diperoleh dari informan I, Informan II, dan Informan III melalui wawancara yang telah dilakukan, dapat ditarik kesimpulan terkait kontrol keputusan pada anak jalanan usia remaja di Kota serang sebagai berikut :

a. Dalam mengambil suatu keputusan, ketiga informan tersebut mampu memikirkan akibatnya dengan matang dan dengan penuh pertimbangan.

b. Kesadaran yang dimiliki oleh anak jalanan usia remaja terhadap pilihan tindakan yang diyakini dan disetujuinya, membuat mereka perlu untuk bersikap bertangggungjawab dan berani mengahadapi akibat atau resiko dari pilihannya tersebut.

\section{Alternatif Layanan Bimbingan dan Konseling yang dapat diberikan Konselor terhadap Anak Jalanan Usia Remaja di Kota Serang}

Self-control pada anak jalanan usia remaja perlu mendapatkan perhatian dan penanganan yang tepat dari berbagai pihak, sehingga mereka dapat bertanggung jawab atas pilihan tindakan atau perilaku yang telah diyakini dan disetujuinya. Alternatif layanan bantuan yang dapat diberikan yaitu berupa Konseling. Dengan melaksanakan konseling oleh konselor ahli ataupun guru Bimbingan dan Konseling diharapkan informan mampu menilai dan mengevaluasi perilakunya selama ini, dan memotivasi diri untuk menjadi lebih baik, serta menjadi lebih bertanggungjawab dari sebelumnya. Sehingga pada akhirnya dapat ditemukan langkah-langkah atau solusi yang dapat diambil untuk membantu informan dalam mengontrol dirinya ketika sedang mengamen ataupun di kehidupan sehariharinya. Serta diharapkan informan mampu 
merencanakan tindakan dalam menggapai impiannya.

\section{Pembahasan}

Deskripsi self-control pada anak jalanan usia remaja di Kota Serang

Dari penelitian yang dilakukan berdasarkan hasil observasi dan wawancara pada beberapa informan yang terlibat dapat diketahui bahwa self-control pada anak jalanan usia remaja di Kota Serang itu memang benar adanya yaitu kurangnya bentuk pengendalian diri mereka sehingga membuat mereka kerap kali melakukan perbuatan yang mengarah pada tindakan negatif, namun dua dari tiga informan tersebut sudah cukup mampu dalam mengontrol dirinya. Pada diri remaja terdapat masa dimana seorang remaja sering mengalami gangguan suasana hati, mempunyai keinginan untuk bebas atau tidak mau diatur dan mencoba hal baru. Disamping itu faktor yang menyebabkan mereka kurang mampu mengendalikan diri yaitu adanya faktor lingkungan sekitar, keluarga dan juga usia mereka. Semakin bertambahnya usia seorang individu, maka semakin baik kemampuan mengontrol dirinya. Sehingga penting bagi anak jalanan usia remaja untuk memiliki kemampuan dalam mengontrol diri. Dengan memiliki self-control diharapkan mampu menahan atau mengendalikan tingkah laku negatif agar tidak merugikan diri sendiri dan orang lain, serta mampu memposisikan dirinya secara baik dengan keluarga, teman maupun masyarakat. Sehingga masyarakat tidak lagi memandang anak jalanan usia remaja di Kota Serang dengan berbagai stigma negatif yang mereka buat.

\section{Kontrol Perilaku pada Anak Jalanan Usia}

\section{Remaja di Kota Serang}

Kemampuan mengontrol perilaku diperinci menjadi dua komponen, pertama ialah kemampuan individu untuk menentukan siapa yang mengendalikan situasi dan keadaan. Apakah diri individu itu sendiri atau aturan perilaku dengan menggunakan kemampuan dirinya dan bila mampu individu tersebuat akan menggunakan sumber eksternal. Kedua, kemampuan untuk mengetahui bagaimana dan kapan stimulus yang tidak dikehendaki dihadapi. Berdasarkan penelitian yang dilakukan terhadap ketiga informan, dapat ditarik kesimpulan yakni, ketiga informan memiliki kemampuan mengontrol diri dalam hal menentukan siapakah yang mengendalikan situasi yaitu berasal dari dalam dirinya sendiri. Hal ini berdasarkan dari ketiga informan yang menunjukkan bahwa yang sebenarnya membuatnya marah yakni bersal dari dirinya sendiri. Namun, ketiganya kurang mampu dalam mengontrol emosi yang muncul.

Ketika marah Informan I dan Informan II lebih menunjukkan ekspresinya dan diselesaikan secara baik-baik serta mampu 
mengendalikan perilakunya untuk tidak melakukan perbuatan negatif yang mengarah kepada tindakan kriminal. Namun, pada Informan III jika dirinya marah atau merasa terganggung informan III kurang mampu dalam mengendalikan perilakunya yang muncul dan kerap kali melakukan perbuatan negatif yang mengarah pada tindakan kriminal, seperti menyakiti teman sepermainanya. Kontrol diri sebagai suatu cara yang dapat membantu remaja dalam mengatur dan mengarahkan perilakunya agar terhindar dari perbuatan yang menyebabkan timbulnya perilaku negatif.

Kontrol Kognitif pada Anak Jalanan Usia Remaja di Kota Serang

Berdasarkan hasil penelitian yang dilakukan melalui observasi dan wawancara pada tiga anak jalanan usia remaja, maka dapat ditarik kesimpulan bahwa dari ketiga Informan tersebut memiliki kemampuan menerima informasi yang mereka butuhkan dan peroleh dengan jelas dan bijak, yakni tidak dengan mudah menerima informasi dan memastikan sumber serta kebenaran dari berita atau informasi tersebut. Selain itu, kedua Informan (Informan I dan II) mampu menyikapi sesuatu yang dikerjakannya dengan penuh pertimbangan dan bertanggung jawab, jika dirasa apa yang mereka kerjakan terjadi sesuatu yang tidak dinginkan mereka akan bertanggungjawab atas akibat tersebut dan menyusun strategi atau pilihan tindakan selanjutnya dengan penuh pertimbangan. Sedangkan pada infroman III tidak terlalu mempertimbangkan dan memikirkan akibat dari apa yang dilakukan dan dikerjakannya dengan penuh pertimbangan, melainkan dengan bersikap pasrah terhadap apapun yang terjadi pada hidupnya. Hikmah dan makna atas terjadinya suatu peristiwa (baik dan buruk) yang mereka alami juga dapat dipahami dan dilihat manfaat serta akibatnya dengan baik dan bijak. Mereka (Informan I dan Informan II) juga mampu memperbaiki diri atas peristiwa yang terjadi dan berusaha untuk menjadi diri yang lebih baik. Sedangkan pada Informan III, dirinya kurang mampu dalam memperbaiki diri atas peristiwa yang terjadi seperti ketika dirinya berulah (melakukan perbuatan yang mengarah ke kriminal) dan ketika dirinya dirazia oleh Petugas Satpol PP berulang kali. Anak jalanan usia remaja dengan kontrol diri yang rendah lebih senang melakukan sesuatu yang beresiko dan melanggar aturan tanpa memikirkan akibatnya dalam jangka panjang.

Kontrol Keputusan pada Anak Jalanan Usia Remaja di Kota Serang

Melihat data lapangan yang telah dilakukan oleh peneliti pada ketiga Informan, diperoleh data yang hampir berkaitan dan serupa dari ketiganya yang sama-sama memiliki kemampuan mengontrol keputusan. 
HaL. 217-231

Ketiganya memiliki kemampuan untuk memilih hasil atau suatu perbuatan berdasarkan pada apa yang telah diyakini dan disetujuinya. Informan I dan Informan II mampu mengontrol keputusanya dengan memilih tindakan berdasarkan pertimbangan yang sebelumnya sudah dipikirkan dengan matang. Sedangkan Informan III terkadang kurang mampu dalam mengontrol keputusan dengan berdasarkan pertimbangan penuh dan jarang memikirkan resiko dari keputusan yang telah dipilihnya tersebut. selain itu, ketiga Informan tersebut mampu bertanggungjawab dengan apa yang telah mereka putuskan, mereka mampu memikirkan akibat atas perbuatan yang mereka lakukan. Ketiganya mampu menghadapi konsekuensi dari perbuatan yang telah mereka lakukan, seperti mampu bertanggungjawab dan menyelesaikan masalah yang dihadapinya seorang diri namun jika diirnya dirasa sudah tidak mampu, mereka tidak sungkan untuk meminta bantuan dari teman-temannya. Remaja dengan kontrol diri yang rendah cenderung akan bertindak cepat dan tiba-tiba, tidak memikirkan resiko yang akan terjadi serta mudah kehilangan kendali saat emosi. Remaja dengan karakteristik tersebut akan cenderung terlibat dalam perbuatan yang mengarah pada tindakan kriminal dari pada remaja yang memiliki kontrol diri yang tinggi.
Alternatif Layanan Bimbingan dan Konseling yang dapat diberikan Konselor terhadap Anak Jalanan Usia Remaja di Kota Serang

Pentingnya kemampuan kontrol diri pada remaja, khususnya pada anak jalanan usia remaja layaknya perlu mendapatkan penanganan dan alternatif bantuan yang sesuai agar mereka dapat mengendalikan dirinya dan terhindar dari perilaku yang mengarah pada tindakan kriminal. Untuk meningkatkan kontrol diri pada anak jalanan usia remaja memang tidak lah dapat dilakukan secara langsung namun tidak dapat di pungkiri juga bahwa kemampuan kontrol diri pada anak jalanan usia remaja dapat ditingkatkan dan perlu mendapatkan arahan yang tepat dari ahli. Berkaitan dengan hal tersebut, kecil kemungkinannya bahwa remaja tersebut tidak dapat menyelesaikan masalahnya sendiri, sehingga patutlah mereka memerlukan bantuan orang lain dan pihak-pihak lainnya yang sesuai dan tepat pada bidangnya. Dikarenakan dari ketiga informan tersebut selain menjadi anak jalanan mereka juga masih menyandang sebagai seorang siswa di sekolah, maka dari itu peran guru Bimbingan dan Konseling di sekolah sangatlah penting untuk membantu meningkatkan kemampuan kontrol diri pada anak jalanan usia remaja agar mereka mampu merencanakan tujuan hidupnya ke arah yang lebih baik. 
Guru Bimbingan dan Konseling atau Konselor ahli dapat membantu remaja dalam menemukan solusi alternatif dalam meningkatkan kontrol diri yang didasarkan pada pemahaman lebih mendalam terkait diri mereka atau konseli, serta mengidentifikasi aspek-aspek lainnya yang berkaitan dengan diri dan keadaan diri mereka atau konseli. Dengan bertemu guru Bimbingan dan Konseling atau konselor ahli tentunya akan ada manfaat yang dapat diambil oleh konseli dari mulai berbagi cerita hingga pada akhirnya sama-sama dapat mencari jalan keluar dari masalah yang dihadapi dan pada akhirnya tercapai tujuan yang diharapkan bersama.

Kasus yang terjadi pada informan disebabkan antara lain karena kurangnya pengendalian diri mereka dalam kemampuan mengontrol perilaku yang juga dipengaruhi oleh lingkungan mereka tinggal dan usia mereka saat ini. Selain itu juga adanya keterangan dari salah satu individu bahwa dirinya kerap kali melakukan perbuatan yang mengarah pada tindakan negatif serta kurang mampu menilai baik buruknya suatu peristiwa yang terjadi pada dirinya. Alternatif bantuan yang sesuai dapat diberikan oleh guru Bimbingan dan Konseling yaitu dengan melakukan proses layanan konseling. Bantuan pemberian layanan Konseling dilakukan dengan didasarkan pada pendekatan dan teknik tertentu yang disesuaikan dengan kondisi dan permasalahan informan sebagai konseli dengan berdasarkan data yang telah diperoleh sebelumnya dari hasil wawancara dan observasi dengan informan.

Konseling didefinisikan oleh Prayitno (Anggraeni, 2015: 76) sebagai bantuan yang diberikan oleh konselor kepada konseli dalam membantu menyelesaikan permasalahan konseli. Dilakukan secara langsung dan tatap muka antara konselor dengan konseli. Dalam segi pembahasan masalah dilakukan secara mendalam dan menyentuh hal-hal penting yang dirasa oleh konseli (hal yang menyangkut rahasia pribadi konseli), bersifat meluas yang meliputi berbagai aspek yang menyangkut permasalahan konseli serta bersifat spesifik. Menurut peneliti, pendekatan yang sesuai untuk Informan I, Informan II, dan Informan III yaitu dengan menggunakan pendekatan Realitas dengan teknik WDEP.

Adapun penjelasan terkait pendekatan Realitas dengan teknik WDEP yakni Pendekatan Realitas merupakan pendekatan dengan fokus tingkah laku saat ini dan merupakan bentuk dari modifikasi perilaku, Corey (2003: 263). Pendekatan Realitas berfungsi membantu konseli dalam menghadapi kenyataan dan memenuhi kebutuhan-kebutuhan dasar tanpa mendatangkan sesuatu yang tidak baik pada dirinya sendiri dan orang lain, serta berani bertanggungjawab atas semua tingkah 
lakunya. Dalam pendeketan Realitas, individu dipandang memiliki kemampuan dalam menentukan dan memilih tingkah lakunya sendiri dengan maksud individu harus mampu bertanggungjawab dan bersedia menerima konsekuensi dari perilakunya. Bertanggungjawab yang dimaksud bukan hanya pada apa yang dilakukannya, namun juga pada apa yang dipikirkannya.

Secara umum, tujuan dari pendekatan Realitas yaitu sama dengan tujuan hidup, yakni individu mampu mencapai kehidupan dengan successidentity. Sehingga individu perlu memiliki kemampuan mencapai kepuasan terhadap kebutuhan pribadinya. Kualitas pribadi sebagai tujuan konseling realitas adalah individu yang memahami dunia nyata dan harus memenuhi kebutuhannya dengan suatu perencanaan yang matang. Untuk mencapai tujuan dari pendekatan Realitas ini maka tentu terdapat peran dan fungsi dari guru Bimbingan dan Konseling atau seorang Konselor yang membantu. Fungsi konselor atau guru Bimbingan dan Konseling yaitu sebagai guru pembimbing untuk konseli sekaligus sebagai model yang baik. Dalam pendekatan Realitas harus bisa menekankan bahwa dalam pendekatan ini bukan hanya untuk kebahagian saja, namun juga mampu bertanggungjawab. Oleh karena itu, konselor atau guru Bimbingan dan Konseling diharapkan mampu memberikan pujian pada saat konseli bertindak secara bertanggungjawab serta menunjukkan ketidak setujuannya pada saat konseli bertindak dengan tidak bertanggungjawab. Sedangkan peran konselor atau guru Bimbingan dan Konseling ialah dengan melibatkan diri dengan konseli yang kemudian membantunya menghadapi kenyataan serta harus bersikap aktif, mendidik, mendorong dan menantang konseli untuk dapat bertanggungjawab pada tingkah lakunya.

Penggunaan tahapan WDEP ini, memiliki tujuan yaitu untuk membantu konseli agar memiliki kemampuan kontrol diri yang lebih besar terhadap kehidupannya sendiri dan mampu membuat pilihan yang lebih baik dari sebelumnya. Diharapkan dengan menggunakan tahapan dari WDEP, konselor mampu mengajak konseli untuk menumbuhkan kesadaran akan pentingnya kontrol diri dengan melakukan evaluasi terhadap dirinya sendiri dengan mengeksplorasi dan menilai perilakunya terutama pada perilaku yang kurang bertanggungjawab yang pada akhirnya mengakibatkan kontrol dirinya rendah dan mengarah pada tindakan negatif. Selanjutnya, setelah mengetahui dan menilai perilakunya konseli bersama dengan konselor membuat perencanaan untuk menentukan perilaku kedepannya agar lebih bertanggungjawab dan memiliki komitmen untuk bertanggungjawab 
terhadap rencana yang telah dibuat dan diyakininya.

Berdasarkan penjabaran tersebut mengenai pendekatan konseling yang dapat diterapkan bagi para informan anak jalanan usia remaja dengan tingkat kontrol diri yang berbeda-beda, pada akhirnya berbagai bantuan maupun layanan Bimbingan dan Konseling dapat digunakan dan diupayakan untuk membantu mereka. Akan tetapi keberhasilan dari suatu proses dan usaha tersebut bergantung pada keinginan masing-masing informan. Apabila keinginan yang dimiliki oleh mereka sangat kuat maka akan sangat membantu untuk tingkat keberhasilan dalam proses pelaksanaan konseling maupun pemberian layanan bantuan lainnya yang dilakukan oleh konselor ahli ataupun guru Bimbingan dan Konseling.

\section{SIMPULAN}

Berdasarkan hasil penelitian yang diperoleh peneliti di lapangan, melalui pengumpulan dan analisis data yang telah dilakukan maka dapat ditarik kesimpulan yakni, Self-control pada anak jalanan usia remaja di Kota Serang itu memang benar adanya yaitu kurangnya bentuk pengendalian diri mereka sehingga membuat mereka sering kali melakukan perbuatan yang mengarah pada tindakan negatif, namun dua dari tiga informan tersebut sudah cukup mampu dalam mengontrol dirinya. Pada masa remaja merupakan masa yang biasanya ditandai dengan ganguan pada suasana hati, mempunyai keinginan untuk hidup bebas dan tidak ingin diatur serta selalu ingin mencoba sesuatu yang baru. Disamping itu faktor yang menyebabkan mereka kurang mampu mengendalikan diri yaitu adanya faktor lingkungan sekitar, keluarga dan juga usia mereka. Dengan adanya beberapa faktor tersebut, membuat setiap individu memiliki bentuk dan tingkat pengendalian diri yang berbeda-beda. Hal ini juga senada dengan bertambahnya usia pada individu, akan berpengaruh pada kemampuan kontrol diri yang dimilikinya menjadi semakin baik. Sehingga penting bagi anak jalanan usia remaja untuk memiliki kemampuan dalam mengontrol diri. Dengan memiliki self-control dapat membantu dalam mengendalikan tingkah laku supaya terhindar dari perbuatan negatif yang merugikan diri sendiri dan orang lain, serta mampu bersikap baik dengan keluarga, teman dan juga masyarakat. Sehingga masyarakat tidak lagi memandang anak jalanan usia remaja di Kota Serang dengan berbagai stigma negatif yang mereka buat.

Faktor dominan yang mempengaruhi self-control pada anak jalanan usia remaja di Kota Serang adalah adanya faktor internal dan eksternal. Faktor internal, yang ikut andil 
terhadap kontrol diri ialah usia. Sedangkan pada faktor eksternal yang dimaksud yaitu adanya pengaruh dari lingkungan keluarga. Selain itu, terdapat faktor lain yang dapat mempengaruhi kontrol diri pada anak jalanan usia remaja yaitu tingkat pendidikan. Anak jalanan yang masih dan sedang menempuh pendidikan akan memiliki kontrol diri yang cukup baik, dibandingkan dengan anak jalanan yang sudah putus sekolah ataupun tidak bersekolah. Alternatif bantuan yang dapat diberikan oleh konselor atau guru bimbingan dan konseling untuk meningkatkan selfcontrol pada anak jalanan usia remaja di Kota Serang yaitu dengan melalui layanan konseling dengan menggunakan berbagai pendekatan sesuai dengan permasalahan yang dialami. Pendekatan yang digunakan pada kasus ini yaitu dengan pendekatan Realitas dan menggunakan teknik atau sistem WDEP.

\section{REFERENSI}

Adeonalia, G. (2002). Hubungan Antara Kontrol Diri Dengan Kecanduan Internet. Skripsi Sarjana pada UNIKA Soegijapranata: diterbitkan.

Amiril, F.A. (2013). Hubungan Antara Kematangan Emosi Dan Kontrol Diri Dengan Stres Kerja Pada Guru SLB Di Kota Malang. Artikel Fakultas Pendidikan Psikologi: diterbitkan
Astri, H. (2014). "Kehidupan Anak Jalanan Di Indonesia: Faktor Penyebab, Tatanan Hidu Dan Kerentanan Berperilaku Menyimpang”. Jurnal Aspirasi, 145-155.

Astuti, M.P. (2019). Tingkat Kontrol Diri Remaja Terhadap Perilaku Negatif (Studi Deskriptif Pada Siswa Kelas VIII SMP Santo Aloysius Turi Tahun Ajaran 2018/2019). Skripsi Sarjana pada USD: diterbitkan.

Averill, J.R. (1973). Personal Control Over Asertive Stimuli and It's Relationship to Stress. Psychological Bulletin. 88, 286-303.

Ghufron, M.N., \& Risnawati, RS. (2010). Teori-Teori Psikologi. Yogyakarta: Ar-Ruzz Media.

Ghufron, M.N., \& Risnawita, RS. (2017). Teori-teori Psikologi. Yogyakarta: Ar-Ruzz Media.

Gunarsa, S.D. (2006). Dari Anak Sampai Usia Lanjut Bunga Rampai Psikologi Perkembangan. Jakarta: PT BPK Gunung Mulia. 
Lestari, N.I. (2019). Teknik Modeling Dalam Menumbuhkan Minat Membaca AlQur'an Pada Anak Jalanan Kota Serang (Studi di Yayasan Bina Wanita Bahagia). Skripsi Sarjana pada UIN Banten: diterbitkan, 1-2.

Muawanah, L.B., \& Pratikto, H. (2012). "Kematangan Emosi, Konsep Diri Dan Kenakalan Remaja”. Jurnal Psikologi. 7, (1), 490-500.

Mubarok, F. (2016). Pengaruh Program Pemberdayaan Rumah Singgah Anak Mandiri Yogyakarta Terhadap Pembentukan Perilaku Religiusitas Anak Jalanan. Skripsi Sarjana pada UIN SUKA: diterbitkan.

Nurfaujiyanti. (2010). Hubungan Pengendalian Diri (Self-Control) dengan Agresivitas Anak Jalanan. Skripsi Sarjana pada UIN Syarif Hidayatullah: diterbitkan.
Rahardjo, M. (2011). Metode Pengumpulan Data Penelitian Kualitatif. uinmalang.ac.id [Online]. Tersedia: https://www.uinmalang.ac.id/r/110601/metodepengumpulan-data-penelitiankualitatif.html [diakses pada 08 Desember 2020].

Rahman, T. (2014). Pengaruh Menghafal Al'Quran Terhadap Peningkatan Kontrol Diri Siswa MTs Miftahul Ihsan Sentol Daya Sumenep Madura. Thesis pada UIN Malang: diterbitkan.

Sugiyono. (2012). Memahami Penelitian Kualitatif. Bandung: ALFABETA

Suyanto, B. (2010). Masalah Sosial Anak. Jakarta: Kencana Prenada Media Group.

Sutoyo, A. (2009). Pemahaman Individu, Observasi, Checklist, Interviu, Kuesioner dan Sosiometri. Yogyakarta: Pustaka Pelajar. 